\title{
Trident Hand: Achondroplasia
}

Chaitanya Yerawar1*, Dileep Punde², Aditi Pandit1 and Prerana Deokar ${ }^{3}$

${ }^{1}$ Department of Endocrinology, Shree Narayana Institute of Medical Superspeciality, India

${ }^{2}$ Punde Hospital, India

${ }^{3}$ Department of Biochemistry, Shree Narayana Institute of Medical Superspeciality, India

Submission: October 10, 2020; Published: November 24, 2020

*Corresponding author: Chaitanya Yerawar, Department of Endocrinology, Shree Narayana Institute of Medical Superspeciality, Nanded, India

\section{Opinion}

Achondroplasia is the most frequent form of short - limb dwarfism [1]. The phenotype is characterized by rhizomelic disproportionate short stature, enlarged head, midface hypoplasia, short hands and lordotic lumbar spine [2,3]. Its incidence is 1 in 10,000 to 1 in 30,000 [1]. Here we describe a case of achondroplasia in a 37-year-old male, who presented to endocrinology OPD for short stature. General physical examination showed large head, depressed nasal bridge short stature, with rhizomelic shortening of the arms and legs and normal trunk length (Figure 1). Patient had short, stubby fingers and excessive spacing between third and fourth finger (Figure 2). Anthropometry revealed a height of $115.5 \mathrm{~cm}$ (midparental height - $155.2 \mathrm{~cm}$ ), weight of $41.4 \mathrm{~kg}$. His vital signs were within the normal limits. Systemic examination did not reveal any abnormality. Hand-wrist radiograph showed short metacarpal and phalanges with trident hand configuration (Figure 3). X ray of lower limb reveled short and thick tubular long bones (Figure 4). Based on clinical examination and radiological features; diagnosis of achondroplasia was confirmed.

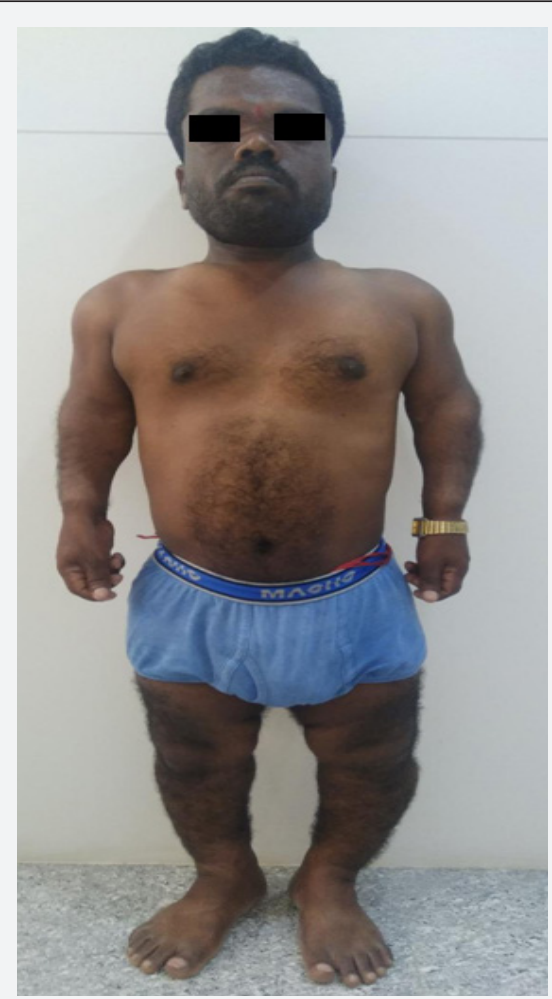

Figure 1: Clinical picture of patient showing short stature, large head, depressed nasal bridge and rhizomelic shortening of arms and legs. 


\section{Journal of Endocrinology and Thyroid Research}

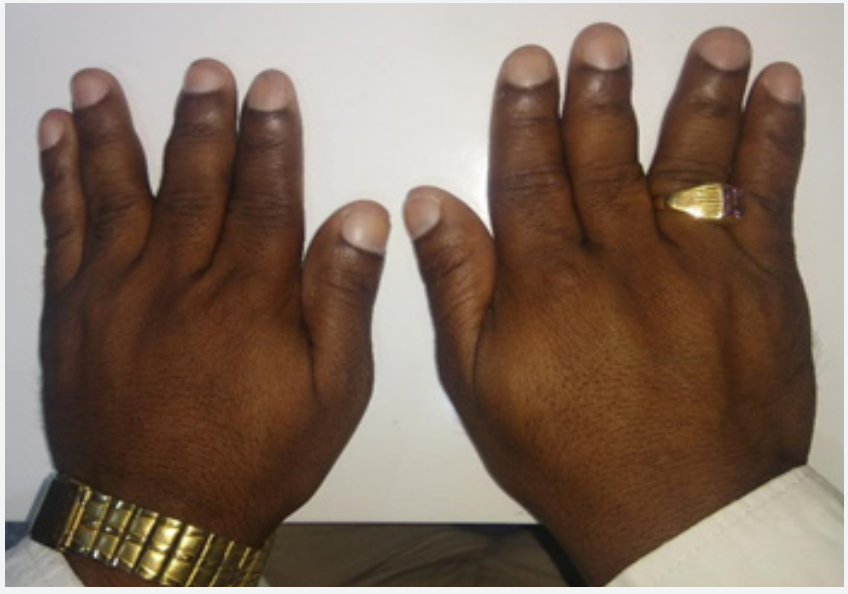

Figure: 2: Short stubby trident hands with increased space between the third and fourth finger.

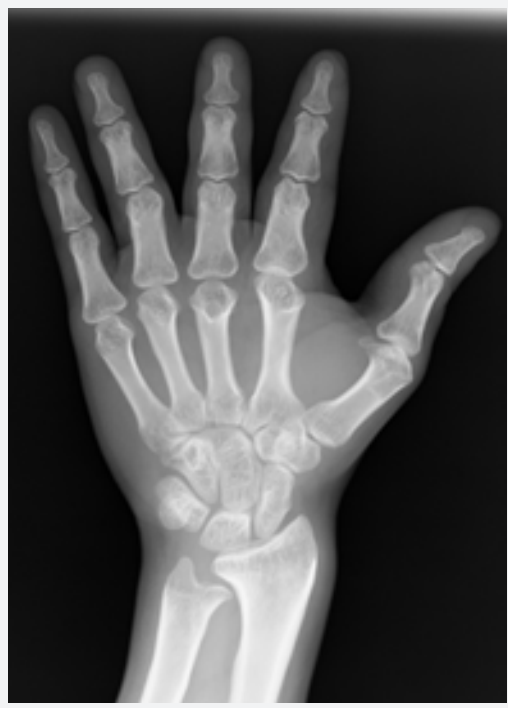

Figure 3: Radiograph of hand showing short metacarpal and phalanges with trident hand configuration.
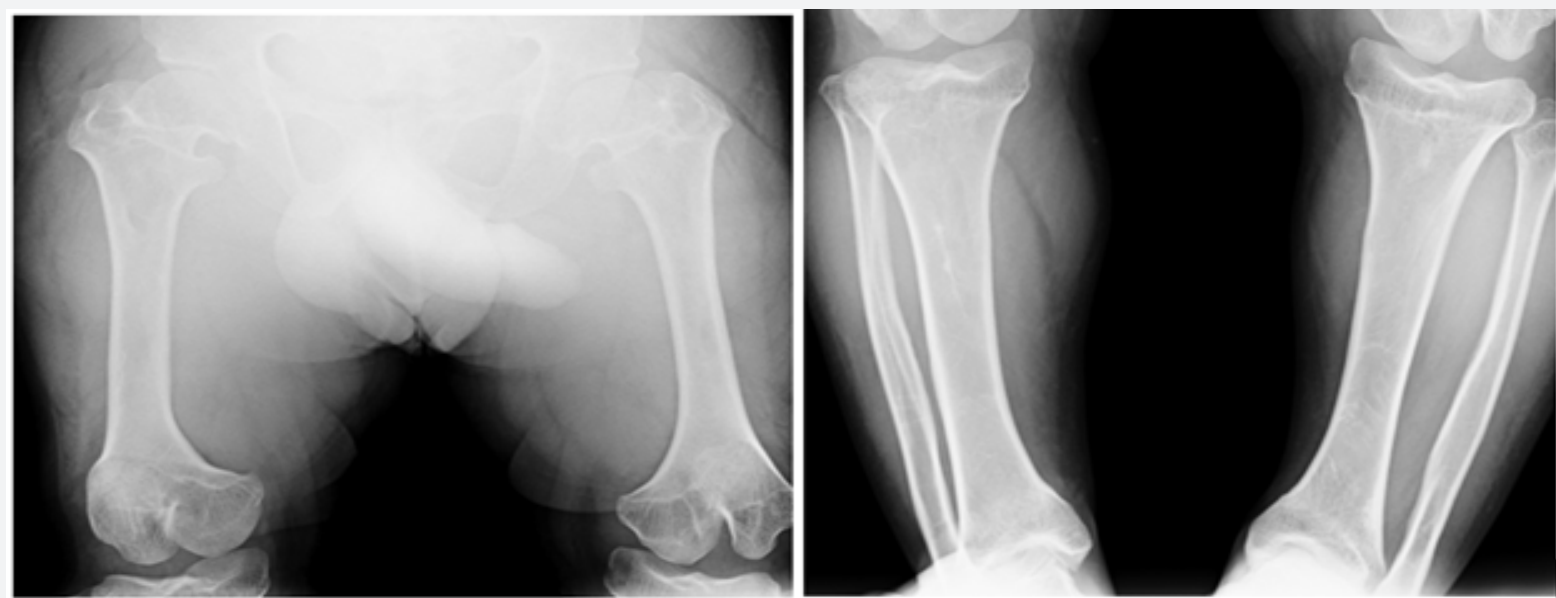

Figure 4: X-ray images of lower limb showing short and thick tubular long bones. 


\section{References}

1. Shah GS, Shrivastava MK, Shah D, Gupta N (2011) Achondroplasia: Case Report and Review of Literature. Journal of Nepal Paediatric Society 31(3): 224-226.

(c) (i) This work is licensed under Creative BY Commons Attribution 4.0 Licens DOI: 10.19080/JETR.2020.05.555672
2. Genevieve Baujat, Laurence Legeai-Mallet, Georges Finidori, Valerie Cormier-Daire, Martine Le Merrer (2008) Achondroplasia. Best Practice \& Research Clinical Rheumatology 22(1): 3-18.

3. Richette P, Bardin T, Stheneur C (2008) Achondroplasia: from genotype to phenotype. Joint Bone Spine 75(2): 125-130.

Your next submission with Juniper Publishers will reach you the below assets

- Quality Editorial service

- Swift Peer Review

- Reprints availability

- E-prints Service

- Manuscript Podcast for convenient understanding

- Global attainment for your research

- Manuscript accessibility in different formats ( Pdf, E-pub, Full Text, Audio)

- Unceasing customer service

Track the below URL for one-step submission https://juniperpublishers.com/online-submission.php 